\title{
Mesobiotus nikolaevae sp.n. (Eutardigrada: Macrobiotidae), a new species of Tardigrada from Croatia
}

\section{D.V. Tumanov}

Department of Invertebrate Zoology, Faculty of Biology, Saint-Petersburg State University, St. Petersburg, 199034, Russia.E-mail: d.tumanov@spbu.ru

ABSTRACT: An illustrated description of Mesobiotus nikolaevae sp.n. (Mesobiotus harmsworthi-group) from Croatia is given. The new species has eyes, smooth cuticle, buccal armature with evident anterior band of teeth, a posterior crown of elongated triangular teeth and a system of three dorsal and three ventral transverse ridges, granulation on all legs and lunules of legs IV without dentation or crenation. This species belongs to Mesobiotus coronatus complex of species by having reticulated conical egg processes with basal ring of short ridges/thickenings. It differs from all known species of this group by having reticulation of the egg surface between the egg processes.

How to cite this article: Tumanov D.V. 2018. Mesobiotus nikolaevae sp.n. (Eutardigrada: Macrobiotidae), a new species of Tardigrada from Croatia // Invert. Zool. Vol.15. No.4. P. 402-419. doi: 10.15298/invertzool.15.4.08

KEY WORDS: tardigrades, Mesobiotus harmsworthi group, Mesobiotus coronatus complex, Mediterranean, Europe, ex Yugoslavia.

\section{Mesobiotus nikolaevae sp.n. (Eutardigrada: Macrobiotidae) - новый вид тихоходок из Хорватии}

\section{Д.В. Туманов}

Кафедра зоологии беспозвоночных, Биологический факультет, Санкт-Петербургский государственный университет, Санкт-Петербург, 199034, Россия. E-mail: d.tumanov@spbu.ru

PЕЗЮМЕ: Дано описание нового вида тихоходок Mesobiotus nikolaevae sp.n. (группа видов harmsworthi) из Хорватии. Новый вид характеризуется наличием глаз, гладкой кутикулой, полностью развитой буккальной арматурой состоящей из передней полосы мелких точек, заднего ряда вытянутых треугольных зубцов и системы из трёх вентральных и трех дорсальных гребней, наличием точечной скульптуры на всех ножках и гладкими лунулами на ножках 4-й пары. Этот вид относится к комплексу видов coronatus, для которого характерны ретикулированные конические выросты хориона яиц, основания которых окружены кольцом радиальных гребней. Он отличается от всех известных видов данной группы наличием ретикуляции на поверхности яиц между выростами.

Как цитировать эту статю: How to cite this article: Tumanov D.V. 2018. Mesobiotus nikolaevae sp.n. (Eutardigrada: Macrobiotidae), a new species of Tardigrada from Croatia // Invert. Zool. Vol.15. No.4. P. 402-419. doi: 10.15298/invertzool.15.4.08

КЛЮЧЕВЫЕ СЛОВА: тихоходки, Tardigrada, группа harmsworthi, coronatus комплекс, Средиземноморская фауна, Европа, бывшая Югославия. 


\section{Introduction}

Little is known about the tardigrades of the Republic of Croatia. During the most part of the XX century, until the Proclamation of independence in 1991, Croatia was a part of the Yugoslavia state (The Kingdom of Yugoslavia in the interwar period and Socialist Federal Republic of Yugoslavia after the Second World War), but most of the faunistic investigations of Yugoslavian tardigrades were held on the territory of Slovenia (Mihelcic, 1938a-e, 1964), and Serbia (Iharos, 1982). Only two papers (Maucci, 1972; Durante Pasa, Maucci, 1975) were devoted to the investigation of the tardigrades of Croatia. Both of them describe the fauna of the Istria peninsula only ( 47 species of Tardigrada, including 11 species of Macrobiotidae). Until now there were no data on the tardigrades of the continental part of Croatia.

In July 2006 I.P. Nikolaeva (Zoological Institute of the Russian Academy of Sciences, St. Petersburg) collected several moss samples in Plitvice Lakes National Park, Croatia. Seven adult and four juvenile specimens and 14 eggs (9 of them embryonated) of Mesobiotus species belonging to the Mesobiotus harmsworthi group were found in one of these samples.

\section{Material and methods}

Tardigrades were extracted using the following procedure: dried moss sample was placed in a plastic container with filtered tap water and leaved overnight for rehydration, then material was vigorously shaken within the container and squeezed over the container, the supernatant was stirred and washed through a system of two sieves: first sieve with $\sim 1 \mathrm{~mm}$ mesh size, and second with $80 \mu \mathrm{m}$ mesh size. This procedure was repeated three times. The content of the fine sieve was washed with the filtered tap water to the Petri dish and screened in portions in the Bogorov's counting chamber under LOMO MBC-10 Stereo Microscope. Tardigrade specimens and eggs were fixed with acetic acid and then mounted on micro- scope slides in Hoyer's medium. Slides were examined under Leica DM 2500 microscope using Phase Contrast (PCM) and Differential Interference Contrast microscopy (DIC). Photographs were made using Nikon DS-Fi1 camera. Three paratype eggs were removed from the slide by dissolving Hoyer's medium with warm $\mathrm{ddH}_{2} \mathrm{O}$, rinsed twice with $\mathrm{ddH}_{2} \mathrm{O}$ to remove medium, air dried and sputter covered with gold. Material was examined under high vacuum in a QUANTA 200 3D Scanning Electron Microscope. All measurements are given in micrometres $(\mu \mathrm{m})$ and were performed under PCM with the eyepiece micrometer, following the Stec et al. (2016) recommendations. Body length was measured from the anterior to the posterior end of the body, excluding the hind legs. Elements of the buccal apparatus and claws were measured according to Kaczmarek \& Michalczyk (2017). For deep structures that could not be fully focused in a single photograph, a series of several images were taken and then assembled into a single deep-focus image using the Helicon Focus software (Helicon Soft Ltd). In the description of the claw structure terms are given according to Guidetti \& Bertolani (2001) and Vecci et al. (2016). Classification of oral cavity armature types is given according to Pilato (1972). The $p t$ index used is the percentage ratio between the length of a structure and the length of the buccal tube (Pilato, 1981). Eggs morphometric data were handled using the "Parachela" ver. 1.2 template available from the Tardigrada Register, www.tardigrada.net/register (Michalczyk, Kaczmarek, 2013).

For comparison, specimens and eggs of Mesobiotus patiens (Pilato et al., 2000) (slide number 4654) and M. simulans (Pilato et al., 2000) (slide numbers 4678 and 5753), all from the collection of Pilato and Binda (University of Catania, Italy), were examined. Photographs of the type specimens of Mesobiotus patiens kindly provided by G. Pilato (University of Catania, Italy) were also used as the comparative material. 


\section{Taxonomy}

Mesobiotus nikolaevae sp.n.

Figs. 1-6, Tables 1, 2.

Holotype: Slide number 232(23) (sex indet.). Collected by Dr. I.P. Nikolaeva (Zoological Institute of the Russian Academy of Sciences, St. Petersburg), 26.07.2006 in Croatia.

Paratypes: Six adult specimens (slides number 232(22), 232(23), 232(24), 232(31), 232(33)), four juvenile specimens (slides number 232(40) and 232(42)) and 14 eggs (slides number 232(25), 232(26), 232(27), 232(28), 232(29), 232(30)) from the same location.

Type locality: Nacionalni park Plitvièka jezera (Plitvice Lakes National Park), Lika-

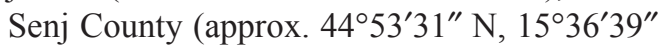
E), moss from stone near the tourist pathway. Together with Echiniscus granulatus (Doyère, 1840), E. spiniger Richters, 1904, E. testudo (Doyère, 1840), E. militaris Murray, 1911, Bryodelphax parvulus Thulin, 1928, Hypsibius microps Thulin, 1928, Hypsibius cf. convergens (Urbanowicz, 1925), Adropion cf. carolae (Binda et Pilato, 1969), Isohypsibius prosostomus Thulin, 1928.

Type depository: Holotype and paratypes of the new species are deposited in the author's collection at Saint-Petersburg State University, Department of Invertebrate Zoology, St. Petersburg, Russia.

Etymology: This species is dedicated to I.P. Nikolaeva, who kindly collected the material for me in Croatia.

Diagnosis: Macrobiotidae with Y-shaped claws. Colour whitish. Three roundish macroplacoids and a relatively large microplacoid close to the last macroplacoid in the pharynx. Buccal armature of the harmsworthi-type with evident anterior band of teeth, a posterior crown of elongated triangular teeth and a system of three dorsal and three ventral transverse ridges. Ornamented eggs, laid freely. Egg shell with reticulated conical processes, their bases with basal crown of ridges, egg surface with wrinkled ridges and relatively large pores between them, forming reticulation-like pattern.

\section{Description.}

Adults. Body length of adult animals 220$345 \mathrm{~mm}$ (Figs. 1A, 3A) (morphometrics in Table 1). Body whitish in live animals and transparent after fixation in Hoyer's medium. Most specimens with black granular eye spots (of the seven adult specimens examined, the eyes were present in five, juvenile specimens and embryos has no eyes). Cuticle of the body is smooth, without pores, tubercles or granulation. Without lateral gibbosity on the hind legs. All legs with areas of granulation. Legs I-III with small areas of granulation on the external surfaces, near the claw bases (Figs. 2B, black arrowhead; $3 \mathrm{E})$, legs IV with better developed granulation dorsally and around the claw bases (Figs. 2D, black arrowhead; 3F). Bucco-pharyngeal apparatus of Macrobiotus type (Figs. 1B, C, 3B). Buccal cavity with ten peribuccal lamellae and buccal armature with evident anterior band of teeth, a posterior crown of elongated triangular teeth and a system of three dorsal and three ventral transverse ridges (Figs. 1D-G, 3C, D). Ventro-lateral ridges with slightly waving anterior edges. Some specimens with few rounded supplementary teeth situated ventrally between posterior crown of teeth and transverse ridges (Fig. 1H, I, arrowheads). Buccal tube with typical ventral lamina. Pharyngeal bulb with apophyses, three macroplacoids and a large microplacoid. First macroplacoid narrower anteriorly, third macroplacoid with a distinct subterminal constriction. Claws of the legs I-III of Mesobiotus type (Figs. 2A, B; 3E) with minute stalk, distinct distal part of the basal portion, short common tract and developed internal septum defining a distal part (Fig. 2A, B, white arrowheads). Primary and secondary branches diverge near the half of claw height, main branches with well-developed accessory points. Claws of fourth pair of legs longer than claws of first three pairs of legs. All claws with lunules, which are distinctly larger and with slightly undulating margins on fourth pairs of legs (Figs. 2A-E, 3F). Anterior (internal) and posterior (external) claws of the legs IV are clearly different in their form: posterior claws has longer common tract and secondary branch diverged from the main branch 

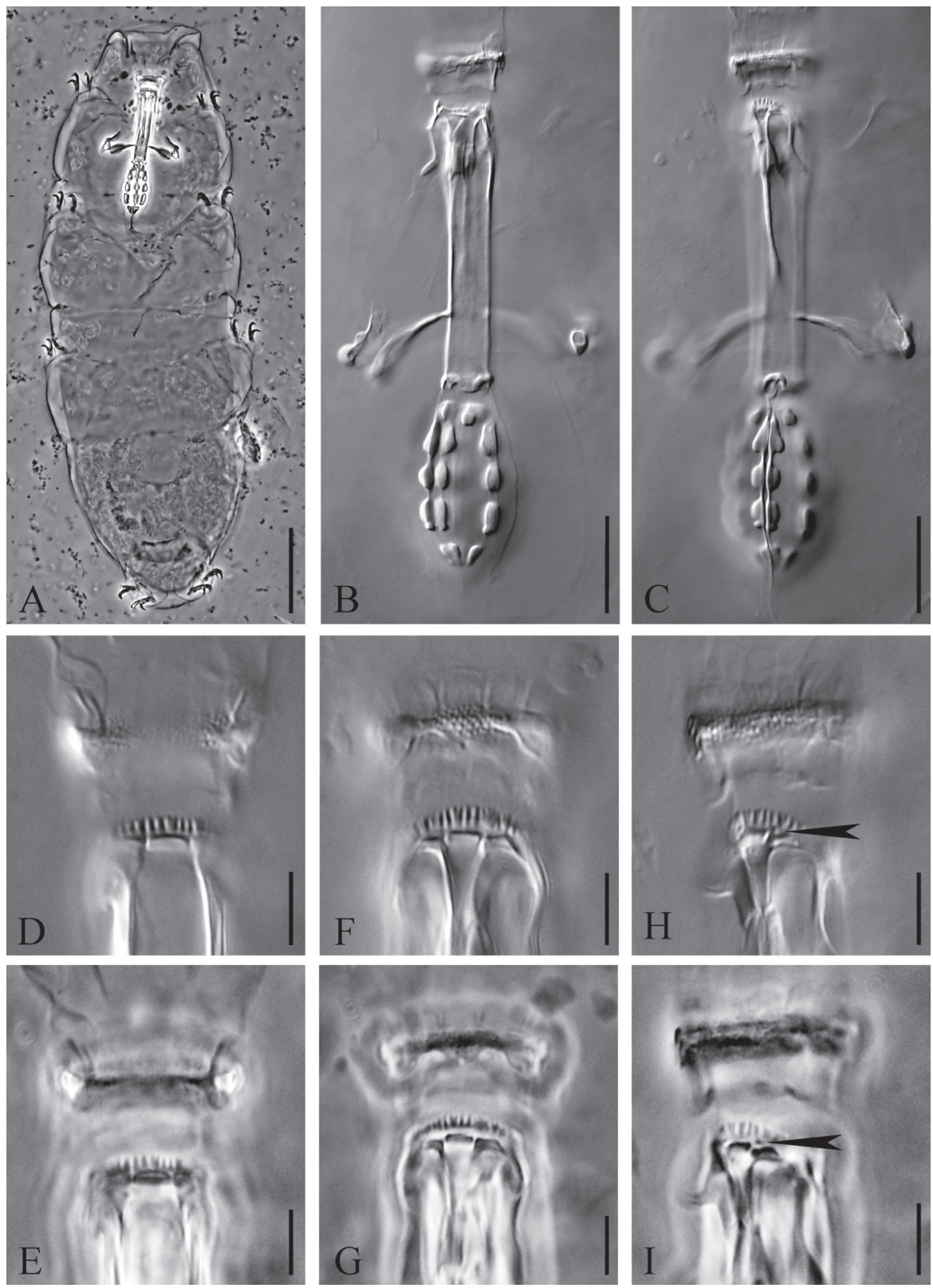

Fig. 1. Mesobiotus nikolaevae sp.n., habitus and bucco-pharyngeal apparatus. A - habitus (holotype); B$\mathrm{C}$ - bucco-pharyngeal apparatus (paratype); D-E - dorsal buccal armature (holotype); F- G - ventral buccal armature (holotype); H-I - ventral buccal armature (paratype), arrowheads indicates to the supplementary tooth.

Scale bar: A $-50 \mu \mathrm{m}$; B, C - $10 \mu \mathrm{m}$; D-I $-5 \mu \mathrm{m}$. A, E, G, I - phase contrast; B, C, D, F, H - DIC.

Рис. 1. Mesobiotus nikolaevae sp.n., общий вид и рото-глоточный аппарат. А - общий вид (голотип); $\mathrm{B}-\mathrm{C}$ - рото-глоточный аппарат (паратип); $\mathrm{D}-\mathrm{E}$ - дорсальная ротовая арматура (голотип); $\mathrm{F}-\mathrm{G}$ вентральная ротовая арматура (голотип); $\mathrm{H}-\mathrm{I}$ - вентральная ротовая арматура (паратип), стрелки указывают на дополнительный зуб.

Масштаб: A $-50 \mu \mathrm{m}$; B, C $-10 \mu \mathrm{m}$; D-I $-5 \mu \mathrm{m}$. A, E, G, I - фазовый контраст; B, C, D, F, H дифференциальный интерференционный контраст. 


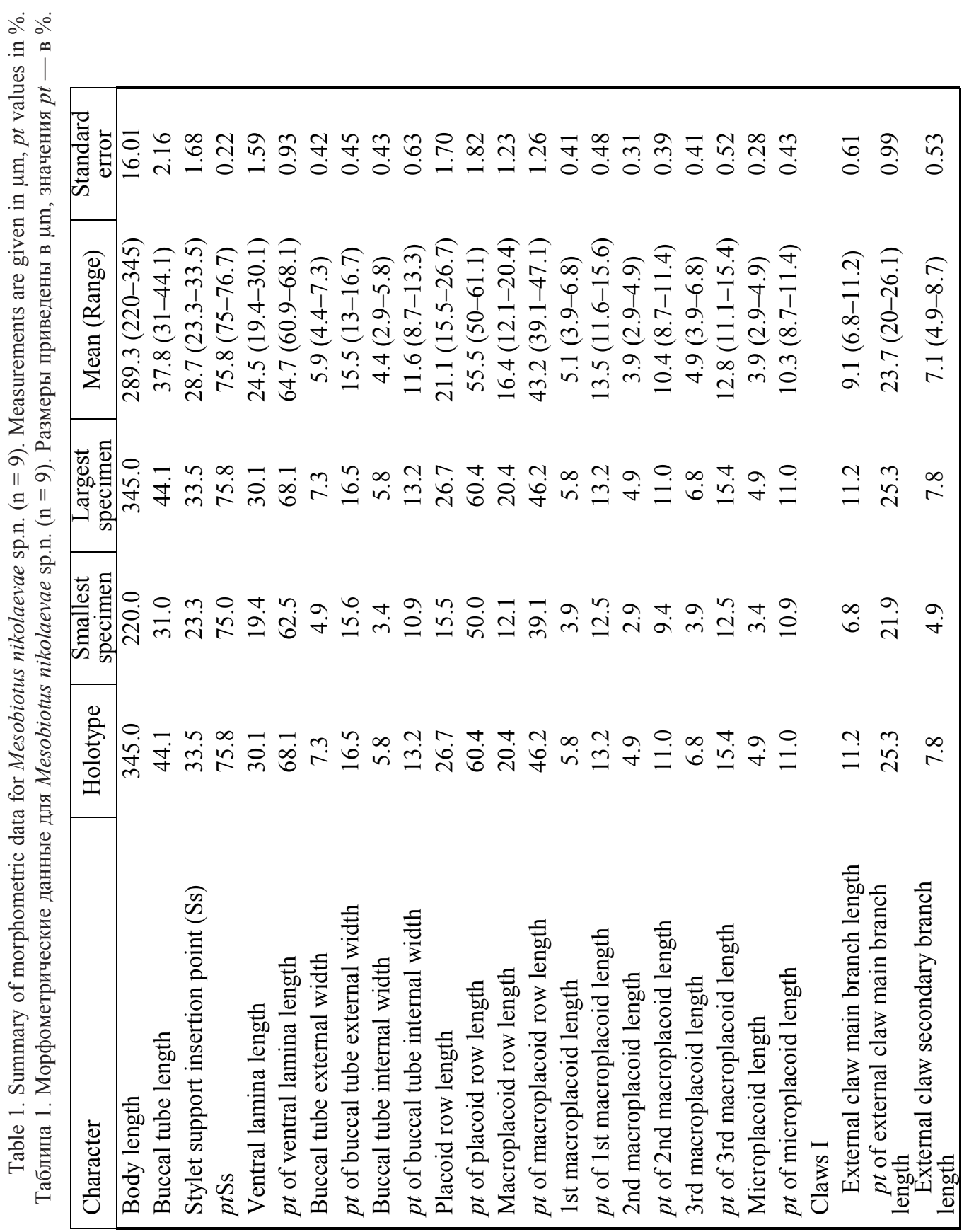




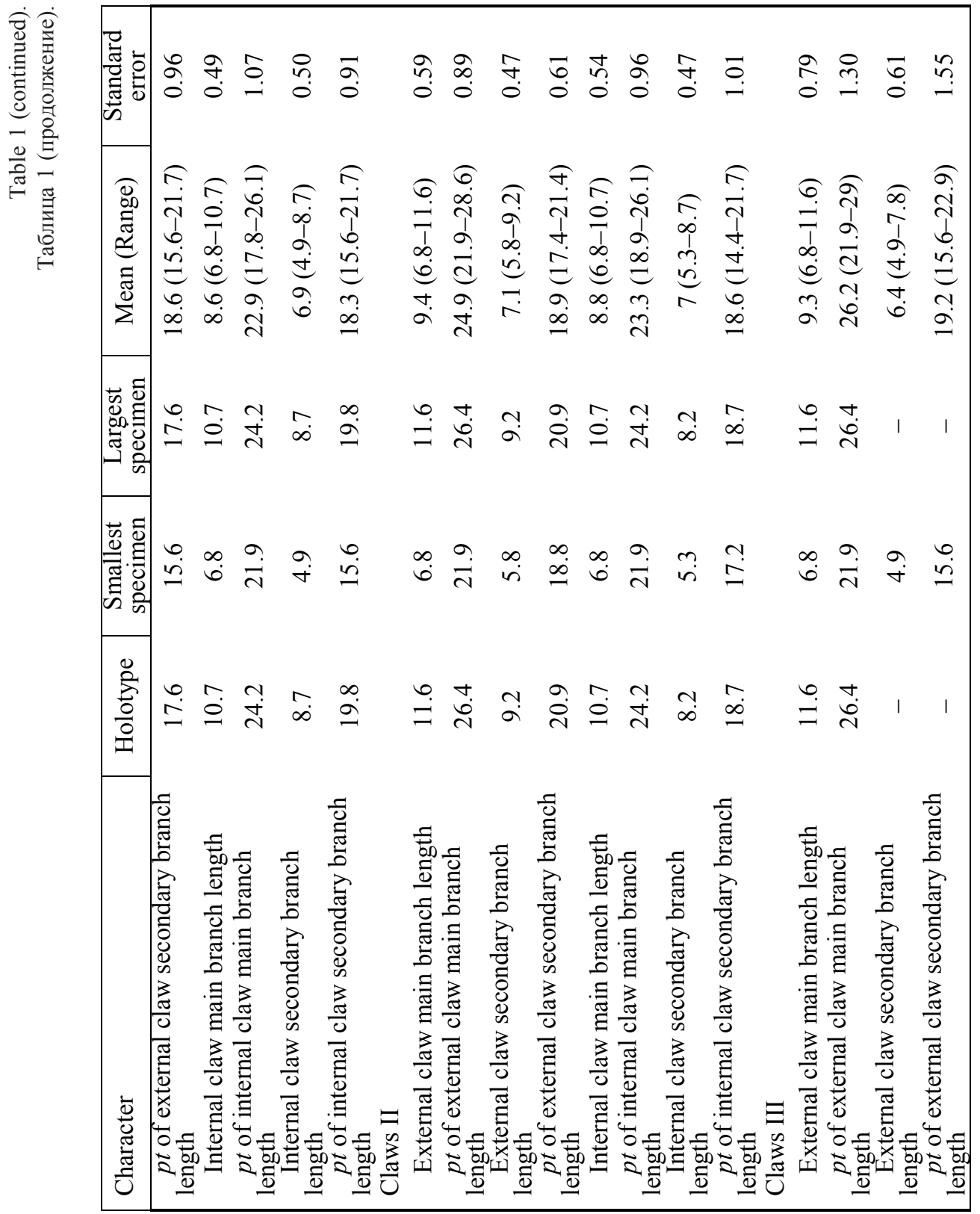



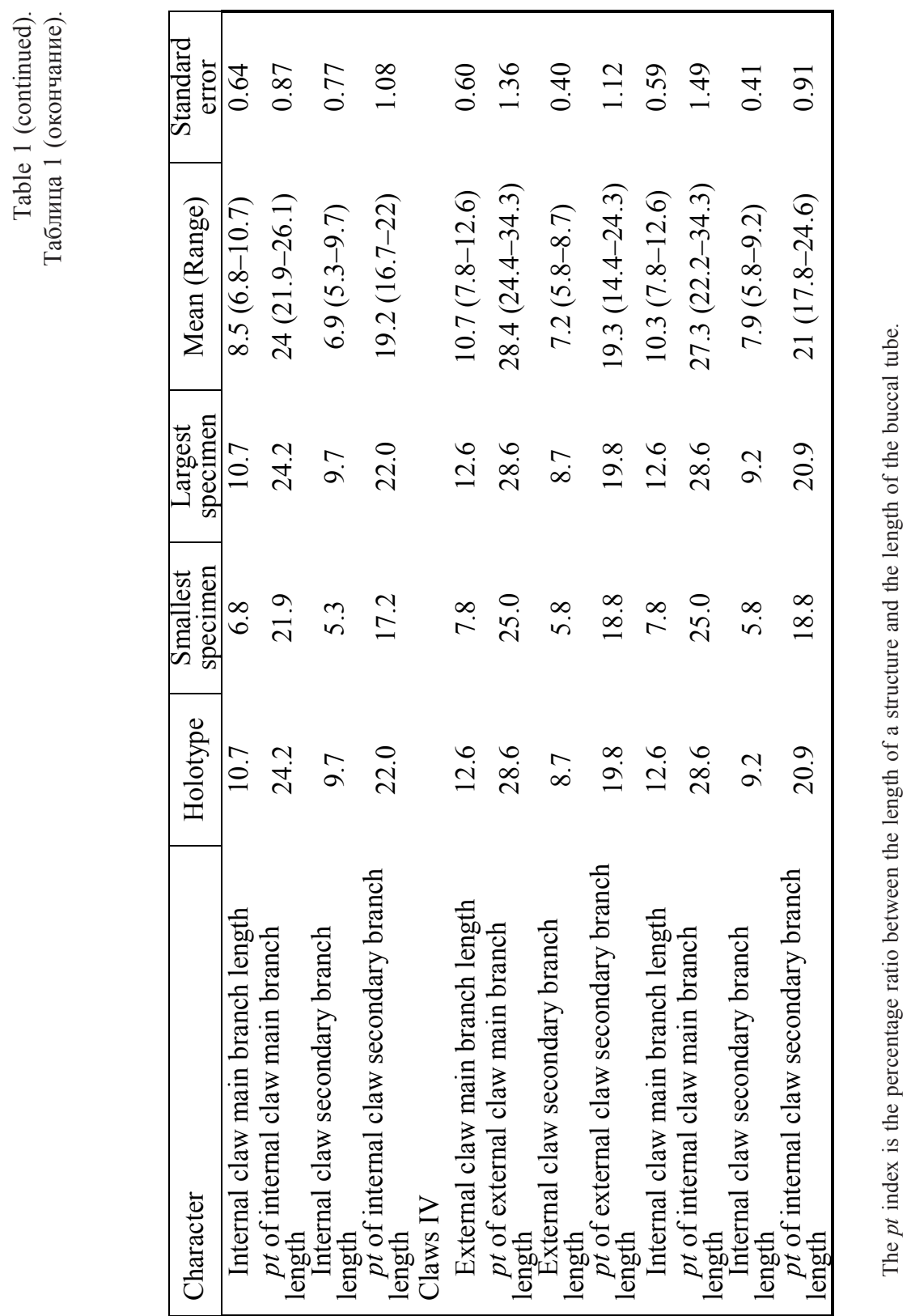

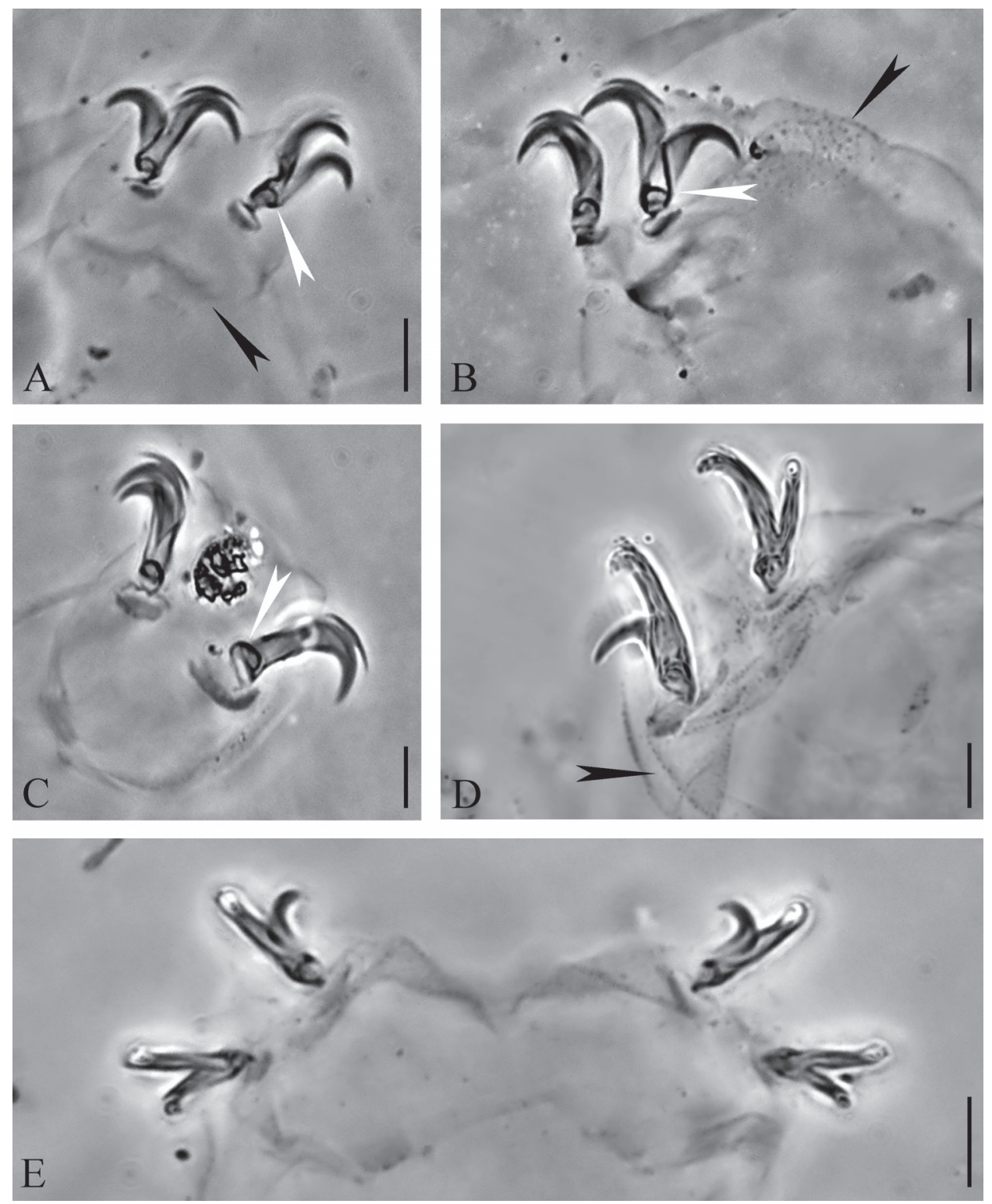

Fig. 2. Mesobiotus nikolaevae sp.n., claws. A - claws of the legs I (paratype), black arrowhead indicates to the cuticular bar, white arrowhead indicates to the internal septum; B - claws of the legs III (paratype), black arrowhead indicates to the cuticular granulation, white arrowhead indicates to the internal septum; C claws of the legs IV (paratype), white arrowhead indicates to the internal septum; D - claws of the leg IV (holotype), black arrowhead indicates to the cuticular granulation; E - claws of the legs IV (paratype).

Scale bar: A-E $-5 \mu \mathrm{m}$. A- E - phase contrast.

Рис. 2. Mesobiotus nikolaevae sp.n., коготки. А - коготки ножки I пары (паратип), черная стрелка указывает на кутикулярную полоску, белая стрелка указывает на внтреннюю септу коготка; В коготки ножки III пары (паратип), черная стрелка указывает на участок с грануляцией, белая стрелка указывает на внтреннюю септу коготка; C - коготки ножки IV пары (паратип), белая стрелка указывает на внтреннюю септу коготка; D - коготки ножки IV пары (голотип), черная стрелка указывает на участок с грануляцией; E - коготки ножки IV пары (паратип).

Масштаб: А-Е - $5 \mu \mathrm{m}$. А-Е - фазовый контраст. 
at the right angle, anterior claws are $\mathrm{V}$-shaped, with shorter common tract (Figs. 2D, E, 3F). On legs IV lunules of the posterior claws are distinctly larger than lunules of the anterior claws (Figs. 2D, E, 3F). Bar-like cuticular thickenings are present below claw bases of the first three pairs of legs (Fig. 2A, black arrowhead).

Eggs spherical, white, ornamented and laid freely (Figs. 4A-C, 6A; morphometrics in Table 2). Chorion with conical processes, with wide bases and thin and flexible apices (Figs. $5 \mathrm{~A}-\mathrm{I}, 6 \mathrm{~B}, \mathrm{G})$. Basal parts of the processes with bilayered walls with a net of trabecular structures between the internal and external layers, forming irregular rounded meshes of different size, so the processes seems to be reticulated under PCM and SEM (Figs. 4D, E, 5C, E, F, 6B-D). SEM observations revealed no circular wrinkles on the outer surface of the processes. Small pores (visible only in SEM) are present on the surface of some processes (Fig. 6C, D, G, black arrowheads). Apical parts of the processes are thin, flexible, with bubble-like internal structure (Figs. 5A, black arrowhead, 6G), smooth outer surface, often branching, sometimes having a tree-like appearance (Figs. 5BF, 6G). Rarely the apical parts are bent downward, to the egg surface (Fig. 5H), or broken (Fig. 5I). Process bases are surrounded by a crown of granules (visible in PCM only, Fig. $4 \mathrm{~B}, \mathrm{D}, \mathrm{E})$, continued to the system of thick winding radial ridges, connected with thinner ridges. Relatively large pores (their diameter is usually equal or exceed the width of the ridges) are present between the ridges (Fig. 6C-F). In PCM this structure could be observed as a very delicate but evident reticular pattern with small isodiametric meshes on the egg surface between processes (Fig. 4D-F). Egg processes are tightly arranged, with the distance between them 1$3 \mu \mathrm{m}$.

\section{Differential diagnosis.}

In having three macroplacoids, relatively large microplacoid close to the last macroplacoid and reticulated conical egg processes $\mathrm{Me}$ sobiotus nikolaevae sp.n. belongs to the harmsworthi group (according to Kaczmarek et al., 2011), and within this group it is most similar to the coronatus species complex to which I attribute here Mesobiotus species with reticulated conical egg processes with bases surrounded with the crown of dot-like structures or radial ridges without areolation or finger-like appendages of the processes bases.

Mesobiotus nikolaevae sp.n. differs from $M$. australis (Pilato, D’Urso, 1976) (known only from type locality in Australia) by having buccal armature of harmsworthi-type with a band of well-developed elongated triangular teeth (M. australis has buccal armature of echinogenitus-type, without such teeth), by having egg processes reticulated ( $M$. australis has nonsculptured egg processes) and by having welldeveloped sculpture of the egg surface between the processes (M. australis has finely punctuated egg surface).

Mesobiotus nikolaevae sp.n. differs from $M$. binieki (Kaczmarek et al., 2011) (known only from type locality in Bulgaria, Europe) by having higher $p t$ of the buccal tube external width (13-16.7\% in M. nikolaevae sp.n. and 12-13.2\% in M. binieki), by having higher $p t$ of the placoid row length (50-61.1\% in M. nikolaevae sp.n. and $42.3-49.6 \%$ in $M$. binieki) and by having different egg morphology: M. binieki has egg processes with very short basal conical part and very long spiniform apical part (much longer than the basal part), while in M. nikolaevae sp.n. apical parts of the processes are subequal to the conical basal part; in M. binieki egg surface between the processes with a system of irregular ridges, while in $M$. nikolaevae sp.n. egg surface with ridges and pores forming a reticulate pattern; M. binieki eggs has 27-32 processes on the egg circumference, while in M. nikolaevae sp.n. eggs has only 12-14 processes.

Mesobiotus nikolaevae sp.n. differs from $M$. coronatus (de Barros, 1942) (reliably known from South America only (Pilato et al., 2000; Kaczmarek et al., 2015)) by having no or only a few supplementary teeth in the ventral buccal armature, by having larger eggs (diameter without processes 54.8-64.9 $\mu \mathrm{m}$ in M. nikolaevae sp.n. and $47-55 \mu \mathrm{m}$ in M. coronatus) with egg processes longer (10.9-18.6 $\mu \mathrm{m}$ in M. nikolaevae sp.n. and 8.3-9.2 $\mu \mathrm{m}$ in M. coronatus) and 

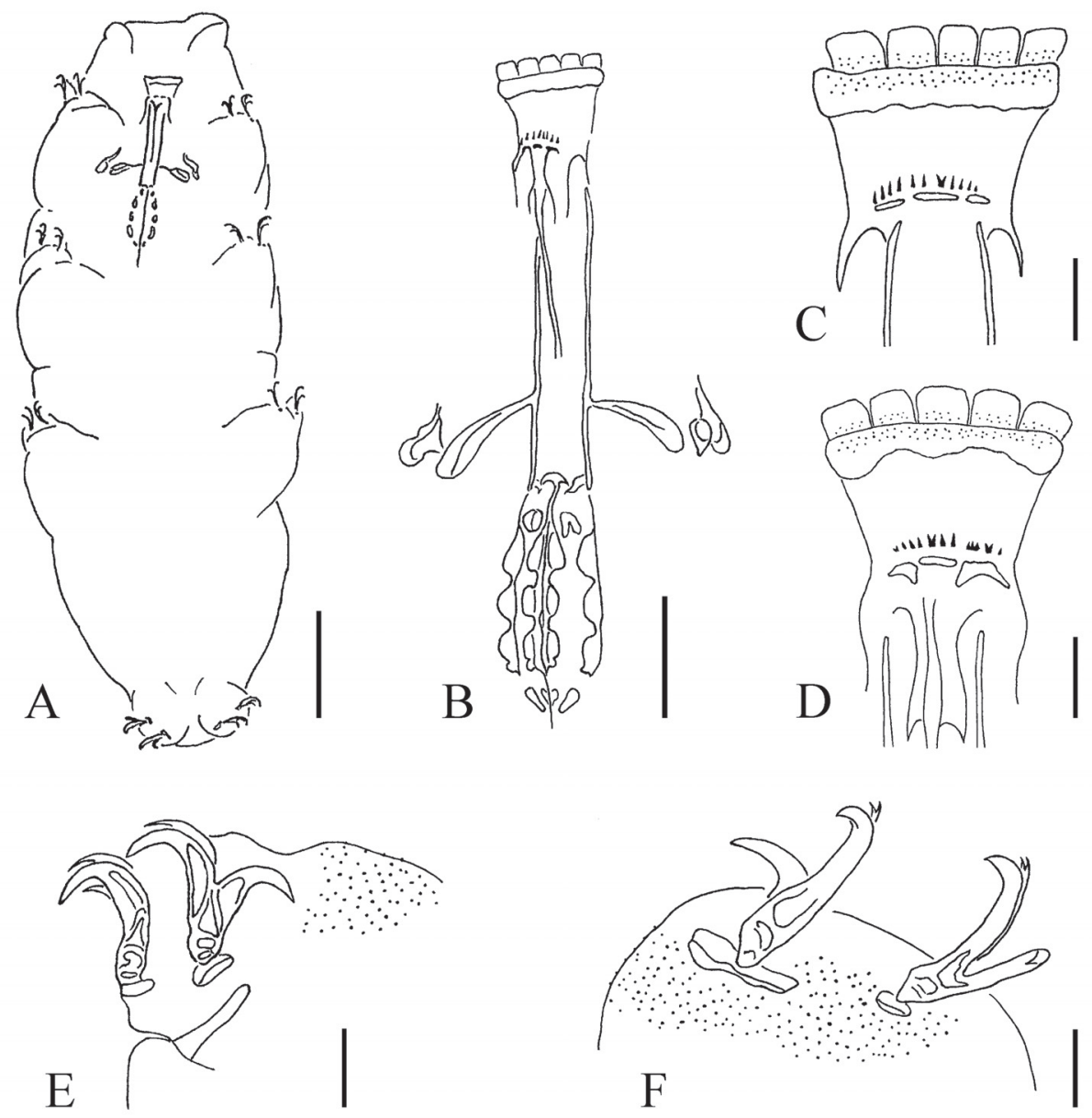

Fig. 3. Mesobiotus nikolaevae sp.n. A - habitus; B — bucco-pharyngeal apparatus; $\mathrm{C}$ - dorsal buccal armature; D - ventral buccal armature; E - claws of the legs III; F — claws of the leg IV.

Scale bar: A $-50 \mu \mathrm{m}$; B, $-10 \mu \mathrm{m} ; \mathrm{C}-\mathrm{F}-5 \mu \mathrm{m}$.

Рис. 3. Mesobiotus nikolaevae sp.n. А - общий вид; В - рото-глоточный аппарат; С — дорсальная ротовая арматура; D - вентральная ротовая арматура; $\mathrm{E}$ - коготки ножки III пары; F — коготки ножки IV пары.

Масштаб: $\mathrm{A}-50 \mu \mathrm{m} ; \mathrm{B},-10 \mu \mathrm{m} ; \mathrm{C}-\mathrm{F}-5 \mu \mathrm{m}$.

wider (11.6-15.5 $\mu \mathrm{m}$ in M. nikolaevae sp.n. and $8.2-10.42 \mu \mathrm{m}$ in $M$. coronatus) and by having egg surface with ridges and pores forming a reticulate pattern (in $M$. coronatus egg surface is dotted).

Mesobiotus nikolaevae sp.n. differs from $M$. diffusus (Binda et Pilato, 1987) (known from North Africa (type locality), Italy, Seychelles (Binda, Pilato, 1995) and New Zealand (Pilato, Binda, 1996)) by presence of eyes, by having stylet supports inserted to the buccal tube in more cephalic position ( $p t S s$ 75-76.7\% in $M$. nikolaevae sp.n. and $77-78.76 \%$ in $M$. diffusus), by having lunules of the legs IV not dentated and by having different egg morphology: $M$. diffusus has egg processes with long thin apical filaments while $M$. nikolaevae sp.n. has egg processes with rarely branching apical parts not forming long filaments; eggs of $M$. diffusus with poorly developed crown of basal 

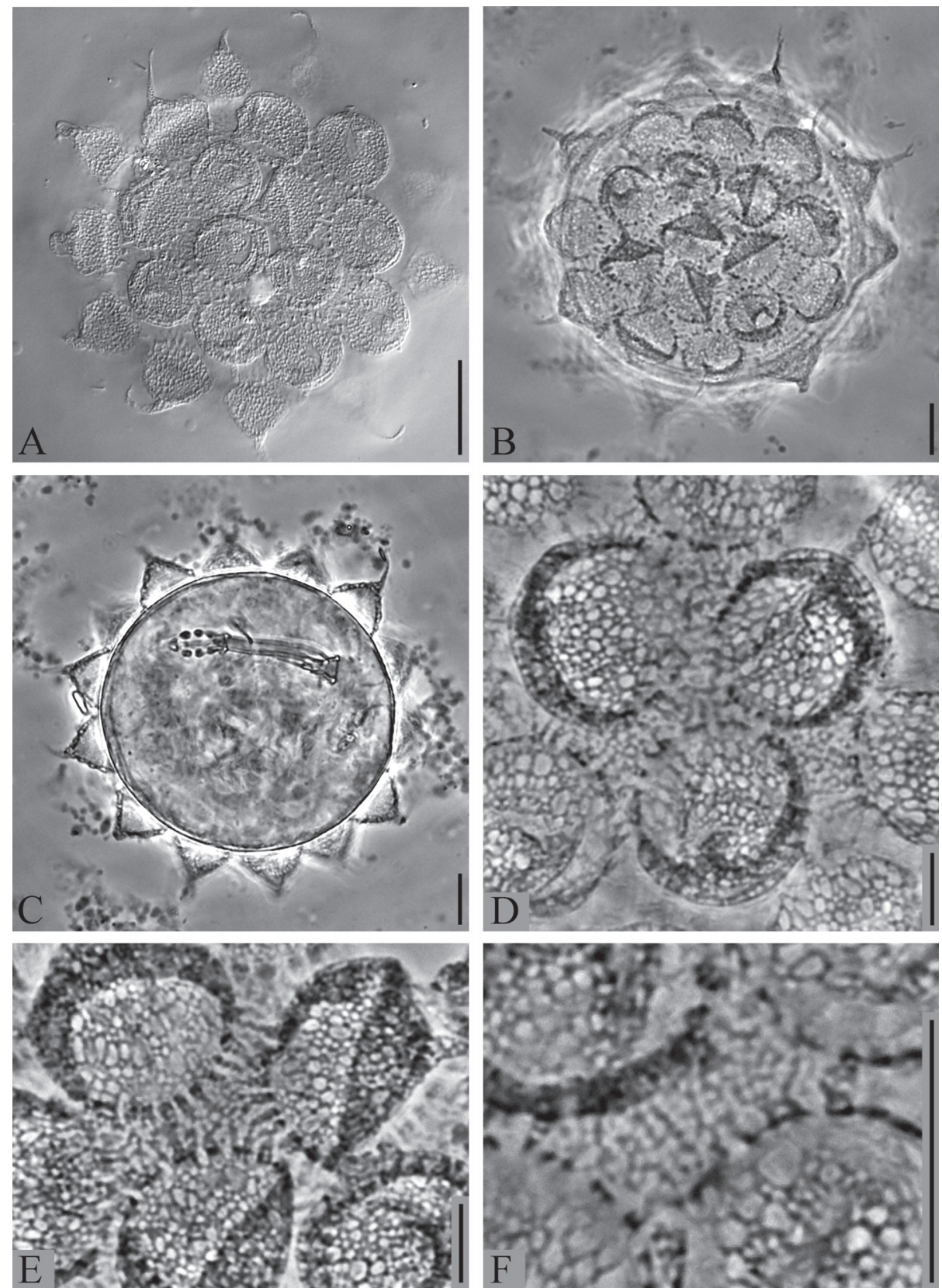

Fig. 4. Mesobiotus nikolaevae sp.n., eggs. A-B - total view of the egg surface; $\mathrm{C}$ - total view of the optical section of the embryonated egg; D-E - details of the egg surface; F — reticulation of the egg surface between the processes.

Scale bar: A-C $-10 \mu \mathrm{m}$; D-F $-5 \mu \mathrm{m}$. A - DIC; B-F - phase contrast.

Рис. 4. Mesobiotus nikolaevae sp.n., яйца. А-В - общий вид поверхности яиц; С - оптический срез яйца с развитым эмбрионом; D-E - структура поверхности яиц, $\mathrm{F}$ - ретикуляция поверхности яйца между выступами хориона.

Масштаб: A-C - $10 \mu \mathrm{m}$; D-F - $5 \mu \mathrm{m}$. А — дифференциальный интерференционный контраст; B-F — фазовый контраст. 

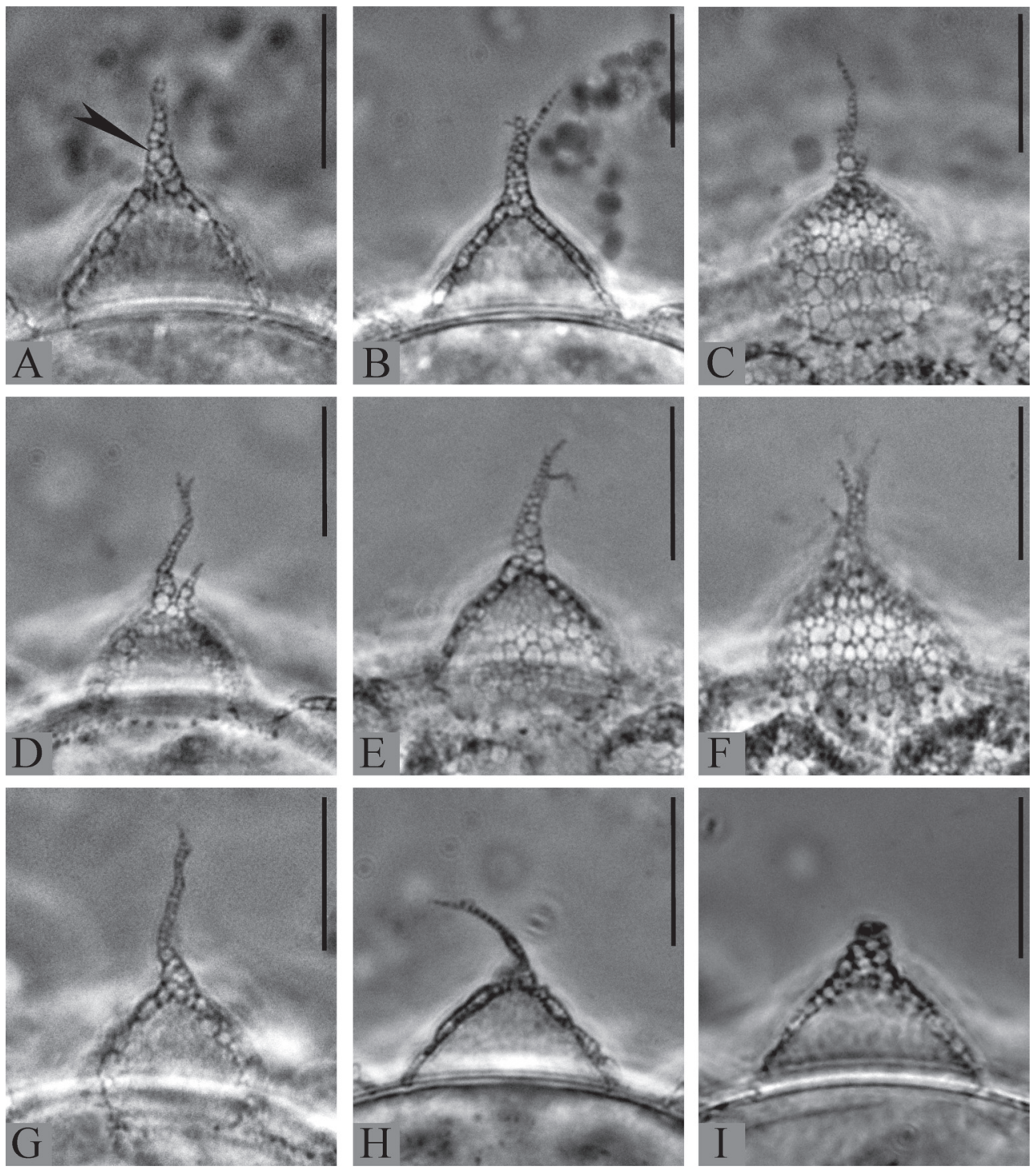

Fig. 5. Mesobiotus nikolaevae sp.n., egg processes. A, B, G, H, I - optical section, arrowhead indicates to the bubble-like internal structure; C, E, F - details of the surface.

Scale bar: A-I - $10 \mu \mathrm{m}$. A-I - phase contrast.

Рис. 5. Mesobiotus nikolaevae sp.n., выступы хориона яиц. А, В, G, Н, I - оптический срез, стрелка указывает на ячеистую структуру апикальной части выроста; C, E, F - структура поверхности. Масштаб: А-I - $10 \mu \mathrm{m}$. А-I — фазовый контраст.

dots while in $M$. nikolaevae sp.n. it is well developed; in $M$. diffusus egg surface between processes with the system of thin radial ridges only while in M. nikolaevae sp.n. egg surface with ridges and pores forming a reticulate pattern.
Mesobiotus nikolaevae sp.n. differs from $M$. dimentmani (Pilato et al., 2010) (known only from type locality in Israel) by having lower $p t$ of the buccal tube external width (13-16.7\% in M. nikolaevae sp.n. and $19.3-23.2 \%$ in $M$. dimentmani), by having lower $p t$ of the length of 

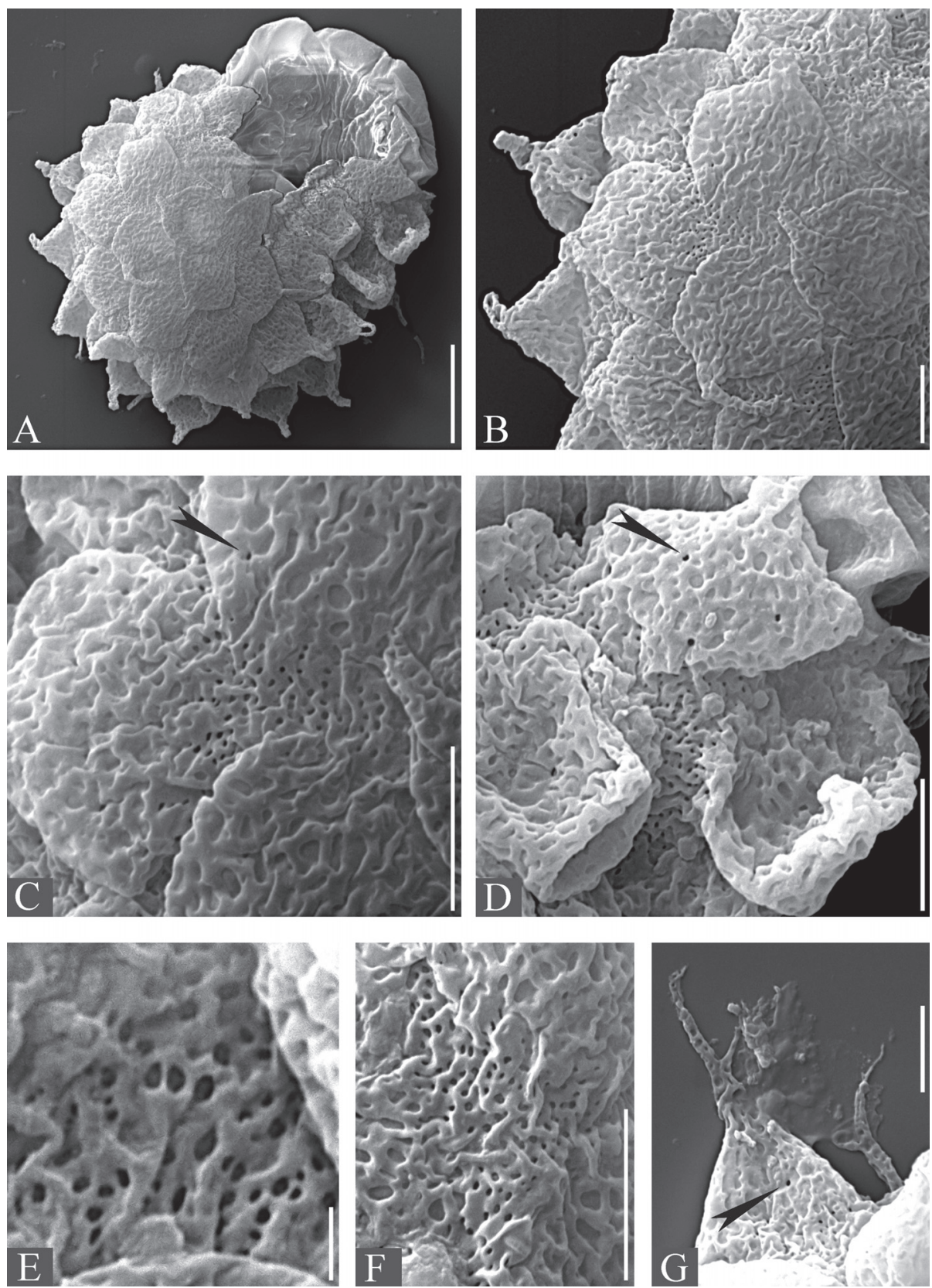

Fig. 6. Mesobiotus nikolaevae sp.n., eggs (SEM). A - total view of the egg; B-D - details of the egg surface; E-F - reticulation of the egg surface between the processes; $\mathrm{G}$ - egg processes. Black arrowheads indicates to the pores on the surface on the egg processes.

Scale bar: A $-15 \mu \mathrm{m} ; \mathrm{B}-\mathrm{D}, \mathrm{F}, \mathrm{G}-5 \mu \mathrm{m} ; \mathrm{E}-1 \mu \mathrm{m}$.

Рис. 6. Mesobiotus nikolaevae sp.n., яйца (сканирующая электронная микроскопия). А 一 общий вид яйца; B-D - структура поверхности яиц; E-F - ретикуляция поверхности яйца между выступами хориона; G - выступ хориона. Черные стрелки указывают на поры на поверхности выступов хориона.

Масштаб: A $-15 \mu \mathrm{m}$; B-D, F, G $-5 \mu \mathrm{m}$; $\mathrm{E}-1 \mu \mathrm{m}$. 
Table 2. Measurements (in $\mu \mathrm{m}$ ) of selected morphological structures of eggs of Mesobiotus nikolaevae sp.n. Таблица 2. Размеры (в $\mu \mathrm{m})$ некоторых деталей строения яиц Mesobiotus nikolaevae sp.n.

\begin{tabular}{|lcccc|}
\hline Character & N & Range & Mean & SD \\
\hline Egg bare diameter & 9 & $54.8-64.9$ & 59.6 & 3.4 \\
Egg full diameter & 9 & $80.2-88.5$ & 82.9 & 2.9 \\
Process height & 39 & $10.9-18.6$ & 14.6 & 1.9 \\
Process base width & 39 & $11.4-15.8$ & 13.5 & 1.0 \\
Process base/height ratio & 39 & $73 \%-146 \%$ & $95 \%$ & $18 \%$ \\
Inter-process distance & 39 & $1.0-3.1$ & 2.0 & 0.6 \\
Number of processes on the egg & 9 & $12-14$ & 13.0 & 0.9 \\
circumference & & & \\
\hline
\end{tabular}

$\mathrm{N}$ - number of eggs/structures measured, Range refers to the smallest and the largest structure among all measured specimens; SD — standard deviation.

the external claws on legs II-III (21.9-29\% in M. nikolaevae sp.n. and $36.3-42.8 \%$ in $M$. dimentmani), by having lunules of the legs IV without dentation, by having smaller eggs (diameter without processes 54.8-64.9 $\mu \mathrm{m}$ in $M$. nikolaevae sp.n. and 79-90 $\mu \mathrm{m}$ in $M$. dimentmani) and by having different egg morphology: $M$. dimentmani has egg processes divided apically to 2-6 long thin apical branches while $M$. nikolaevae sp.n. has egg processes with rarely branching apical parts not forming long branches; in $M$. dimentmani egg surface between processes is dotted while in M. nikolaevae sp.n. egg surface with ridges and pores forming a reticulate pattern.

Mesobiotus nikolaevae sp.n. differs from $M$. harmsworthi (Murray, 1907) (this species is often considered to be cosmopolitan, but is reliably noted from European localities only, records from other regions should be treated as dubious) by having lower $p t$ of the buccal tube external width (13-16.7\% in M. nikolaevae sp.n. and $16.7-20.7 \%$ in $M$. harmsworthi), by having smaller eggs (diameter without processes 54.8-64.9 $\mu \mathrm{m}$ in M. nikolaevae sp.n. and 69$83.5 \mu \mathrm{m}$ in $M$. harmsworthi), by having different processes morphology (in M. harmsworthi egg processes are wider (base diameter 14.5-22 $\mu \mathrm{m})$, without distinct elongated and branched apical part and with very poorly developed basal crown of dots) and by having egg surface with ridges and pores forming a reticulate pattern (egg surface is granulated in M. harmsworthi).
The comparison based on the M. harmsworthi harmsworthi description by Pilato et al. (2000) and morphometric data provided by Pilato \& Lisi (2006).

Mesobiotus nikolaevae sp.n. differs from $M$. insuetus (Pilato et al., 2014) (known only from type locality in Sicily, Italy, Europe) by the presence of eyes, by having lower $p t$ of the buccal tube external width $(13-16.7 \%$ in $M$. nikolaevae sp.n. and $18.2-19.7 \%$ in $M$. insuetus), by having stylet supports inserted to the buccal tube in more cephalic position ( $p t S s$ 75$76.7 \%$ in M. nikolaevae sp.n. and $79-79.4 \%$ in $M$. insuetus), by having claws of the legs II-III shorter than claws of the legs IV (in M. insuetus claws of the hind pair of legs are slightly shorter than claws of the legs II-III), and by having longer egg processes (10.9-18.6 $\mu \mathrm{m}$ in $M$. nikolaevae sp.n. and 7.9-8.6 $\mu \mathrm{m}$ in M. insuetus) and egg surface with ridges and pores forming a reticulate pattern.

Mesobiotus nikolaevae sp.n. differs from $M$. patiens (Pilato et al., 2000) (known from Aeolian Islands (type locality) and several islands in Tyrrhenian Sea, Italy, Europe (Pilato et al., 2000)) by having lower $p t$ of the buccal tube external width (13-16.7\% in M. nikolaevae sp.n. and $17.9-21.1 \%$ in M. patiens), by having stylet supports inserted to the buccal tube in more cephalic position ( $p t S s$ 75-76.7\% in $M$. nikolaevae sp.n. and $77.4-79.1 \%$ in $M$. patiens), and by having smaller eggs (diameter without processes $54.8-64.9 \mu \mathrm{m}$ in M. nikolae- 

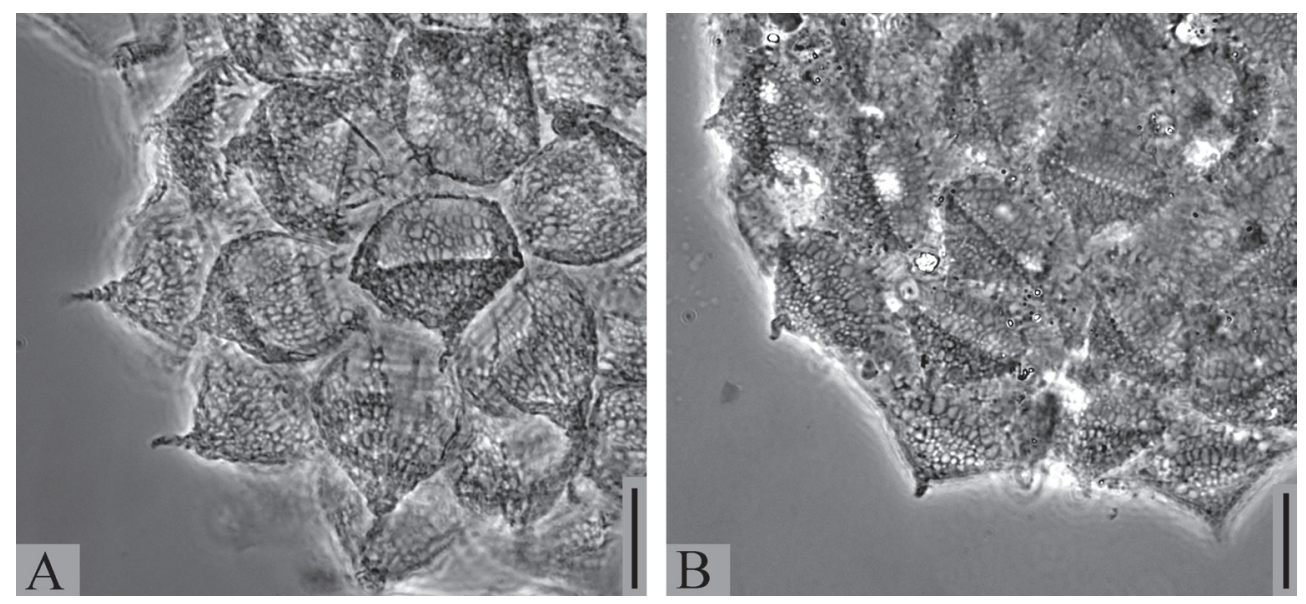

Fig. 7. Mesobiotus patiens and Mesobiotus simulans, eggs. A - Mesobiotus patiens egg; B - Mesobiotus simulans egg.

Scale bar: A, B - $10 \mu \mathrm{m}$. Phase contrast.

Рис. 7. Mesobiotus patiens и Mesobiotus simulans, яйца. А — яйцо Mesobiotus patiens; В — яйцо Mesobiotus simulans.

Масштаб: А, В - $10 \mu$ m. Фазовый контраст.

vae sp.n. and $75-87 \mu \mathrm{m}$ in M. patiens) with egg processes with relatively longer apical parts and egg surface with ridges and pores forming a reticulate pattern (egg surface is granulated in M. patiens) (Fig. 7A).

The comparison based on the M. patiens description by Pilato et al. (2000), and morphometric data provided by Pilato \& Lisi (2009).

Mesobiotus nikolaevae sp.n. differs from $M$. perfidus (Pilato et Lisi, 2009) (known only from type locality in Seychelles Islands) by having smooth body cuticle (cuticle with small tubercles in $M$. perfidus), by having granulation on legs I-III, by having anterior band of teeth in the buccal armature, and by egg surface with ridges and pores forming a reticulate pattern (in $M$. perfidus egg surface with dot-like sculpture).

Mesobiotus nikolaevae sp.n. differs from $M$. philippinicus Mapalo et al., 2016 (known only from type locality in Philippines) by having stylet supports inserted to the buccal tube in slightly more cephalic position ( $p t S s$ 75-76.7\% in M. nikolaevae sp.n. and $76.4-79.8 \%$ in $M$. philippinicus), by having undivided medio-ventral ridge of the buccal armature (medio-ventral ridge is splitted into $2-4$ round or oval teeth in M. philippinicus), by having lower $p t$ of the length of the claws ( $p t$ for external claws II is $21.9-28.6 \%$ in M. nikolaevae sp.n. and 29.3$33.5 \%$ in M. philippinicus), by having lunules of the legs IV without denticles. The eggs of $M$. nikolaevae sp.n. are similar to the eggs of $M$. philippinicus by having egg surface between processes with combination of higher and thicker radial ridges, derived from the dots of the basal crown, and lower thin ridges, connecting them transversely. The following differences allow to distinguish eggs of these species: (1) egg processes of $M$. philippinicus usually with strong wrinkles, making their surface serrated in light microscopy while in M. nikolaevae sp.n. the surface of the egg processes surface is usually only slightly undulated in PCM, without wrinkles; (2) in M. philippinicus pores between the ridges of the egg surface are sparsely distributed, without forming a network pattern, their diameter is usually smaller than the width of the ridges while in M. nikolaevae sp.n. pores of ther egg sufface are larger and distributed more regular, forming a reticulate pattern; (3) in $M$. philippinicus branching apical parts of the egg processes often covered with small granules while in M. nikolaevae sp.n. they are smooth (visible only in SEM); (4) M. nikolaevae sp.n. 
has smaller eggs (diameter without processes 54.8-64.9 $\mu \mathrm{m}$ in M. nikolaevae sp.n. and 62.7$79.9 \mu \mathrm{m}$ in M. philippinicus); (5) M. nikolaevae sp.n. has longer egg processes $(10.9-18.6 \mu \mathrm{m}$ in M. nikolaevae sp.n. and 2.1-13.7 $\mu \mathrm{m}$ in $M$. philippinicus).

Mesobiotus nikolaevae sp.n. differs from $M$. pseudoblocki Roszkowska et al., 2016 (known only from type locality in Argentina, South America) by having granulation on all legs (granulation absent in M. pseudoblocki), by having stylet supports inserted to the buccal tube in more caudal position ( $p t S s$ 75-76.7\% in M. nikolaevae sp.n. and $71.5-75.2 \%$ in $M$. pseudoblocki), by having smaller eggs (diameter without processes $54.8-64.9 \mu \mathrm{m}$ in $M$. $n i$ kolaevae sp.n. and 62.4-69.4 $\mu \mathrm{m}$ in M. pseudoblocki), by having larger egg processes (height $10.9-18.6 \mu \mathrm{m}$ and base width $11.4-15.8 \mu \mathrm{m}$ in M. nikolaevae sp.n. vs $10.5-12.8 \mu \mathrm{m}$ and 5.8$7.7 \mu \mathrm{m}$ respectively in $M$. pseudoblocki), and by having egg surface with ridges and pores forming a reticulate pattern (smooth in M. pseudoblocki).

Mesobiotus nikolaevae sp.n. differs from $M$. pseudocoronatus (Pilato et al., 2006) (known only from type locality in Seychelles Islands) by having smooth body cuticle (cuticle with small tubercles in M. pseudocoronatus), by having lunules of the legs IV without indentations, and by having egg surface with ridges and pores forming a reticulate pattern (in M. pseudocoronatus egg surface with dot-like sculpture).

Mesobiotus nikolaevae sp.n. differs from $M$. pseudopatiens Kaczmarek et Roszkowska, 2016 (known only from type locality in Costa Rica, South America) by the presence of eyes, by having granulation on legs I-III, by having anterior band of teeth in the buccal armature (the anterior band of teeth absent in M. pseudopatiens) and by having egg surface with ridges and pores forming a reticulate pattern (in M. pseudopatiens egg surface is covered with granules or small wrinkles without reticulation).

Mesobiotus nikolaevae sp.n. differs from $M$. radiatus (Pilato et al., 1991) (known only from type locality in Tanzania, Africa) by the significantly smaller body size (up to $345 \mu \mathrm{m}$ in $M$. nikolaevae sp.n. and up to $630 \mu \mathrm{m}$ in M. radia$t u s$ ), by the presence of eyes, by having lower $p t$ of the placoid row length $(50-61.1 \%$ in $M$. nikolaevae sp.n. and $64.1 \%$ in M. radiatus), by having lunules of the legs IV without denticles, by having smaller eggs (diameter without processes 54.8-64.9 $\mu \mathrm{m}$ in M. nikolaevae sp.n. and $85.74 \mu \mathrm{m}$ in $M$. radiatus) and by having different egg morphology: M. radiatus has egg processes with reticulated conical basal part and unsculptured (or very poorly sculptured) cylindrical apical part with a visible septum between them and indented apex while M. nikolaevae sp.n. has apical parts of the egg processes in a form of relatively thin filament with evident internal vesicular structure and often with relatively long branches.

Mesobiotus nikolaevae sp.n. differs from $M$. rigidus (Pilato et Lisi, 2006) (known only from type locality in New Zealand) by the presence of eyes and granulation on legs I-III, by having no or only a few supplementary teeth in the ventral buccal armature, by having flexible and often branched apical parts of the egg processes (rigid and undivided in $M$. rigidus) and by having egg surface with ridges and pores forming a reticulate pattern (in M. rigidus egg surface is granulated).

Mesobiotus nikolaevae sp.n. differs from Mesobiotus romani Roszkowska et al., 2018 (known only from type locality in Ecuador, South America) by having undivided medioventral ridge of the buccal armature (medioventral ridge is splitted into 2 round teeth in $M$. romani), by having lower $p t$ of the length of the external claws on legs II-III (21.9-29\% in $M$. nikolaevae sp.n. and $28.6-36.5 \%$ in M. romani), by having lunules of the legs IV not dentate and by having smaller eggs (diameter without processes $54.8-64.9 \mu \mathrm{m}$ in M. nikolaevae sp.n. and 62.0-85.0 $\mu \mathrm{m}$ in M. romani) with smaller number of processes on the egg circumference (12-14 in M. nikolaevae sp.n. and 1617 in M. romani).

Mesobiotus nikolaevae sp.n. differs from $M$. simulans (Pilato et al., 2000) (known from Sardinia (type locality), several locations in Italy, Europe (Pilato et al., 2000) and Israel 
(Pilato et al., 2010)) by having lower $p t$ of the buccal tube external width $(13-16.7 \%$ in $M$. nikolaevae sp.n. and $17.5-29.1 \%$ in $M$. simulans), by having stylet supports inserted to the buccal tube in more cephalic position ( $p t S s$ 75$76.7 \%$ in M. nikolaevae sp.n. and 77.6-79.4\% in $M$. simulans), by having longer egg processes (10.9-18.6 $\mu \mathrm{m}$ in M. nikolaevae sp.n. and up to $11 \mu \mathrm{m}$ in $M$. simulans), by having egg processes with longer apical part in relation to the basal conical part, and by having egg surface with ridges and pores forming a reticulate pattern (egg surface is finely granulated in M. simulans) (Fig. 7B).

The comparison based on the M. simulans description by Pilato et al. (2000), and morphometric data provided by Pilato \& Lisi (2009).

Mesobiotus nikolaevae sp.n. differs from $M$. wuzhishanensis (Yin et al., 2011) (known only from type locality in China, Asia) in significantly smaller body size (up to $345 \mu \mathrm{m}$ in $M$. nikolaevae sp.n. and up to $610 \mu \mathrm{m}$ in $M$. wuzhishanensis), by having slightly higher $p t$ of the buccal tube external width $(13-16.7 \%$ in $M$. nikolaevae sp.n. and $11.3-13.4 \%$ in M. wuzhishanensis ), by having lower $p t$ of the length of the claws I-III ( $p t$ of the length of the external claws II $21.9-28.6 \%$ in M. nikolaevae sp.n. and $29.4-36.6 \%$ in $M$. wuzhishanensis), by having lunules of the legs IV without denticles, by having smaller eggs (diameter without processes 54.8-64.9 $\mu \mathrm{m}$ in M. nikolaevae sp.n. and 85.8 $\mu \mathrm{m}$ in $M$. wuzhishanensis), and by having egg surface with ridges and pores forming a reticulate pattern (in the description of M. wuzhishanensis egg surface is described as smooth, but some ridges are visible between the processes in figures 5 and 10 (Yin et al., 2011)).

\section{Acknowledgements}

I would like to thank Irina Nikolaeva (Zoological Institute, Russian Academy of Sciences, St-Petersburg) for collecting the material studied here. I am most grateful to Prof. G. Pilato (University of Catania, Italy) for sending me slides and photos of M. patiens and M. simulans. I am also thankful to anonymous reviewers for valuable comments on the manuscript. This study used equipment of the Core Facilities Centers "Culture Collection of Microorganisms", "Centre for Molecular and Cell Technologies" and "Centre for Microscopy and Microanalysis" of Saint-Petersburg State University.

\section{References}

Binda M.G., Pilato G. 1987. Tardigrada dell'Africa. V. Notizie sui Tardigradi del Nord-Africa e descrizione della nuove specie Macrobiotus diffusus // Animalia. Vol.14. No.1/3. P.177-191.

Binda M.G., Pilato G. 1995. Remarks on tardigrades from the Seychelles, with a description of two new species // Trop. Zool. Vol.8. P.1-6.

de Barros R. 1942. Tardigrados de Estado de Sao Paulo, Brasil. II. Gênero Macrobiotus // Rev. Brasil Biol. Vol.2. P.373-386.

Durante Pasa M.V., Maucci W. 1975. Tardigradi muscicoli dell'Istria con descrizione di due specie nuove // Mem. Ist. Ital. Idrobiol., Pallanza. Vol.32. Suppl. P.69-91.

Iharos G. 1982. Tardigradologische Notizen, I // Misc. Zool. Hungarica. T.1. P.85-90.

Guidetti R., Bertolani R. 2001. An evolutionary line of the Macrobiotinae (Tardigrada, Macrobiotidae): Calcarobiotus and related species // Ital. J. Zool. Vol.68. P.229-233.

Kaczmarek Ł., Gołdyn B., Prokop Z.M., Michalczyk Ł. 2011. New records of Tardigrada from Bulgaria with the description of Macrobiotus binieki sp. nov. (Eutardigrada: Macrobiotidae) and a key to the species of the harmsworthi group // Zootaxa. Vol.2781. P.2939.

Kaczmarek Ł., Michalczyk Ł. 2017. The Macrobiotus hufelandi group (Tardigrada) revisited // Zootaxa. Vol.4363. No.1. P.101-123.

Kaczmarek Ł., Michalczyk Ł., McIness S.J. 2015. Annotated zoogeography of non-marine Tardigrada. Part II: South America // Zootaxa. Vol.3923. No.1. P.1-107.

Kaczmarek Ł., Roszkowska M. 2016. A new eutardigrade from Costa Rica with taxonomical and zoogeographical remarks on Costa Rican tardigrades // N.Z. J. Zool. Vol.43. No.3. P.234-245.

Mapalo M.A., Stec D., Mirano-Bascos D., Michalczyk $£$. 2016. Mesobiotus philippinicus sp. nov., the first limnoterrestrial tardigrade from the Philippines // Zootaxa. Vol.4126. No.3. P.411-426.

Maucci W. 1972. Due nuove specie di tardigradi muscicoli dell'Istria // Mem. Mus. Civ. St. Nat. Verona. Vol.20. P.1-8.

Michalczyk Ł., Kaczmarek Ł. 2013. The Tardigrada Register: a comprehensive online data repository for tardigrade taxonomy // J. Limnol. Vol.72(S1). P.175181.

Mihelčič F. 1938a. Beiträge zur Kenntnis der Tardigraden Jugoslawiens I // Zool. Anz. Bd.121. P.95-96. 
Mihelčič F. 1938b. Beiträge zur Kenntnis der Tardigraden Jugoslawiens II // Zool. Anz. Bd.121. P.349-350.

Mihelčič F. 1938c. Beiträge zur Kenntnis der Tardigraden Jugoslawiens III // Zool. Anz. Bd.122. P.318-321.

Mihelčič F. 1938d. Beiträge zur Kenntnis der Tardigraden Jugoslawiens IV // Zool. Anz. Bd.123. P.316-318.

Mihelčič F. 1938e. Beiträge zur Kenntnis der Tardigraden Jugoslawiens V. Die Tardigraden der Hölen und Grotten des Karstes // Zool. Anz. Bd.123. P.318-319.

Mihelčič F. 1964. Eine neue Echiniscus-Art (Tardigrada) aus Karst (Echiniscus (E.) inocellatus n. sp.) // Zool. Anz. Bd.172. P.239-242.

Murray J. 1907. Arctic Tardigrada, collected by Wm. S. Bruce // Trans. R. Soc. Edinburgh. Vol.45. P.669-681.

Pilato G. 1972. Structure, intraspecific variability and systematic value of the buccal armature of Eutardigrades // J. Zool. Syst. Evol. Res. Vol.10. No.1. P.6578.

Pilato G. 1981. Analisi di nuovi caratteri nello studio degli Eutardigradi // Animalia Vol.8. P.51-57.

Pilato G., Binda M.G. 1996. Two new species and new records of Macrobiotus (Eutardigrada) from New Zealand // N.Z. J. Zool. Vol.23. P.375-379.

Pilato G., Binda M.G., Catanzaro R. 1991. Remarks on some tardigrades of the African fauna with the description of three new species of Macrobiotus Schultze 1834 // Trop. Zool. Vol.4. P.167-178.

Pilato G., Binda M.G., Lisi O. 2006. Three new species of eutardigrades from Seychelles // N.Z. J. Zool. Vol.33. P.39-48.

Pilato G., Binda M.G., Napolitano A., Moncada E. 2000. The specific value of Macrobiotus coronatus DeBarros 1942, and description of two new species of the harmsworthi group (Eutardigrada) // Boll. Acc. Gioenia Sci. Nat. Vol.33. P.103-120.

Pilato G., D’Urso V. 1976. Contributo alla conoscenza dei Tardigradi d'Australia // Animalia. Vol.3. P.135145.
Pilato G., Lisi O. 2006. Macrobiotus rigidus sp. nov., new species of eutardigrade from New Zealand // Zootaxa. Vol.1109. P.49-55.

Pilato G., Lisi O. 2009. Tardigrades from Seychelles Islands, with the description of three new species // Zootaxa. Vol.2124. P.1-20.

Pilato G., Lisi O., Binda M.G. 2010. Tardigrades of Israel with description of four new species // Zootaxa. Vol.2665. P.1-28.

Pilato G., Sabella G., Lisi O. 2014. Two new tardigrade species from Sicily //Zootaxa. Vol.3754. No.2. P.173184.

Roszkowska M., Stec D., Ciobanu D.A., Kaczmarek Ł. 2016. Tardigrades from Nahuel Huapi National Park (Argentina, South America) with descriptions of two new Macrobiotidae species // Zootaxa. Vol.4105. No.3. P.243-260.

Roszkowska M., Stec D., Gawlak M., Kaczmarek Ł. 2018. An integrative description of a new tardigrade species Mesobiotus romani sp. nov. (Macrobiotidae: harmsworthi group) from the Ecuadorian Pacific coast // Zootaxa. Vol.4450. No.5. P.550-564.

Stec D., Gąsiorek P., Morek W., Kosztyła P., Zawierucha K., Michno K., Kaczmarek Ł., Prokop Z.M., Michalczyk Ł. 2016. Estimating optimal sample size for tardigrade morphometry // Zool. J. Linn. Soc. Vol.178. No.4. P.776-784.

Vecchi M., Cesari M., Bertolani R., Jönsoon I.K., Guidetti R. 2016. Integrative systematic studies on tardigrades from Antarctica identify new genera and new species within Macrobiotoidea and Echiniscoidea // Invertebr. Syst. No.3. P.303-322.

Yin H., Wang L., Li X. 2011. Two new species of genus Macrobiotus (Tardigrada: Macrobiotidae) from China // Proc. Biol. Soc. Wash. Vol.124. No.3. P.165178.

Responsible editor E.N. Temereva 